\title{
The Impact of Political Instability on Madagascar Vanilla Exports
}

\author{
Anselme Andriamahery*, Jun Zhou \\ School of Economics, Wuhan University of Technology, Wuhan, China \\ Email: *andriamaheryanselme@yahoo.fr, zhoujun601@sina.com
}

How to cite this paper: Andriamahery, A. and Zhou, J. (2018) The Impact of Political Instability on Madagascar Vanilla Exports. Open Journal of Social Sciences, 6, 27-38. https://doi.org/10.4236/jss.2018.64003

Received: March 3, 2018

Accepted: April 15, 2018

Published: April 18, 2018

Copyright $\odot 2018$ by authors and Scientific Research Publishing Inc. This work is licensed under the Creative Commons Attribution International License (CC BY 4.0).

http://creativecommons.org/licenses/by/4.0/

\section{(c) (i) Open Access}

\begin{abstract}
The main purpose of this paper is to investigate how the political instability in 2009 affected the Madagascar vanilla exports. Madagascar vanilla sector has experienced robust growth over the past decade which contributes to both the economy and the job creation, especially in northeast region where Vanilla was planted. However, this growth faced a serious problem after the political instability in 2009. This paper shows that the suspension of Africa Growth and Opportunity Act (AGOA), due to the political instability, had a large negative impact on vanilla exports. To estimate its impacts on vanilla exports, the international trade data permit us to isolate those impacts from various factors between Madagascar and other vanilla exporting countries by using the different-in-different (DID) technique. We take the sample of 2007 to 2011 by using Tobit model with random effects in addition to OLS with fixed effect in order to observe how far political instability hampers the vanilla exports in Madagascar. Through analysis, we find that the political instability has a negative effect on economic growth in terms of Madagascar vanilla exports.
\end{abstract}

\section{Keywords}

Political Instability, Economic Growth, Madagascar Vanilla Exports, Suspension of AGOA

\section{Introduction}

In today's world, political instability remains the most questionable issues and hard to tackle. Too many countries have faced this turmoil especially in Sub-Saharan Africa (SSA). Madagascar, which is located in the Southern Indian Ocean, has experienced cycles of political instability over the last five decades. However, it is well-known by its nature and among the one enormous potential on cash crop, namely vanilla, coffee, and cloves. And despite its recent progress, 
Madagascar is shaken by a profound political instability in 2009. Yet, in the context of domestic political turmoil together with the global economic crisis, the Malagasy economy has not been growing since the second quarter of 2009. Weak governance and inefficiency of political parties remain the key constraints to Madagascar's development. The governance and financial management challenges have been both the cause and consequence of this crisis. The absence of concrete and effective follow-up within government, the inappropriate mingling of public and private interests and institutional weaknesses has reduced the level of efficiency, transparency and liability of government action. Therefore, Malagasy people have felt unsatisfied and powerless and even have lost their trust and hope on their leaders. And this led people to oust President Marc Ravalomanana in military-backed coup in March 2009 and replaced by Andry Rajoelina who took power to lead a transitional government. The international organization has suspended most aid, except on humanitarian and poverty grounds, on which the country is highly dependent. In January 2010, Madagascar couldn't have access on AGOA as the American government revoked the country's eligibility. And like most other donors, the World Bank has suspended new lending and grants.

Vanilla is a member of the orchid family, which is a native of Mexico. It was brought to Madagascar in the 1890s by French colonists, and is generally produced in the North-East coast of Madagascar. Most of the country's vanilla beans are grown in the humid and wet climate of the rainforest covering the SAVA (Sambava, Antalaha,Vohémar, and Andapa) region, where about $70 \%$ of the population depend on this lucrative and fragrant spice. Thus, the principal economic motor for the SAVA region has been the vanilla industry, with production of green vanilla increasing from 4000 to 10,000 tons between 1994 and 2004 [1]. The species most commonly grown in Madagascar is "Vanilla planifolia" or "Vanilla fragrant". After planting, the vanilla vines, which grow around trees, need two or three years to start flowering, and each flower lasts one day only before they get pollinated. The flowers are pollinated by hand due to the lack of natural pollinators in the country. Remarkably, the majority of Madagascar's vanilla is produced by small-scale plantation farming dominated by family operations rather than large-scale production, with the average farmer cultivating 3000 to 4000 feet of vanilla. Overall, 1000 feet of vanilla plants can yield 500 $\mathrm{Kg}$ (kilograms) of green vanilla generating $100 \mathrm{Kg}$ of processed vanilla. The process of vanilla processing involves several players, beginning with the planter, who either sells the green pods to a buyer or processes the vanilla himself and then sells it to an exporter who, in turn, sends the processed beans to buyers in USA and European countries.

\section{Literature Review}

\subsection{Theoretical Background: Madagascar Political Instability in 2009-2012}

At the end of the year 2007, Andry Rajoelina was elected as a mayor of the capi- 
tal of Madagascar (Antananarivo). However, there were problems happened between the mayor and the President Marc Ravalomanana in 2008. And different angles of unpopular policies ratified by the president were criticized by Andry Rajoelina. In the same year, the government apparently delayed to pay the funds for various local government infrastructure projects in the capital, and even diverted investment away from the city. And in too many other ways, they refused to facilitate cooperation between the municipal and the central governments. Many people said that the government's strategies were intended to undermine Andry Rajoelina. He also criticized the President Ravalomanana who agreed that large parts of Malagasy land are leased to the company Daewoo from Korea. Furthermore, the mayor of the capital found a linked business interests between President Marc Ravalomanana and his party TIM (Tiako i Madagasikara) which needs to be controlled. The Malagasy political instability became very serious when a young mayor was self-proclaimed as the president of Madagascar on March $21^{\text {st }} 2008$.

\subsection{Political Instability and Economic Growth}

Political instability is the qualitative phenomena which are difficult to measure quantitatively and not easily to define.

\subsubsection{Definition of Political Instability}

Political stability provided a description of a well-functioning government while political instability is the propensity of a government collapse either because of conflicts or rampant competition between various political parties [2]. An early study tells us that there is no general consensus in literature about how to define political instability. Despite that, we can refer to Lipset (1960) [3] who defined political instability as the non-persistence in form of government. It was said that a politically stable country has been a liberal democracy or autocracy for at least 25 years [4]. In addition, according to Alesina and Perotti (1996) [5], political instability is the "propensity to observe the government changes" and the changes can take place within the law or outside, like "Coups d'État" and that differentiates between constitutional and unconstitutional government changes. In this case, revolutions are a sign of political instability which can be provoked by individuals who lose confidence, are dissatisfied in the political system and demonstrate to show their anger or dissatisfaction.

\subsubsection{Determinants of Political Instability}

\section{1) Economic Inequality}

It is important to state that the power given to the government influences the leaders of some countries to make a change in economic and social policies for their personal interests, not for their nations. Such an anti-social behavior would harm the economic performance hence the birth of economic inequality. With a polarized and inequality distribution of national resources, people will find reasons to pursue their interest outside the normal channels of both political repre- 
sentation and market activities. Therefore, people in unequal societies, as Perotti (1996) [6] stated, are "more prone to engage in rent-seeking activities or other manifestations of socio-political instability, such as violent protests, assassinations, and coups" which have been seen in Malagasy society lately. Edward Muller (1985) [7] commented that: "it seems plausible to expect that in societies with high inequality, where the distribution or scope of discontent is presumably widespread, discontent is highly likely to be mobilized somehow, than in societies with low inequality."

\section{2) Income}

In reference to Blanco and Grier (2009) [8], they consider that poor economic performance mainly causes political instability and this is down to two reasons. The first reason is that falling income lowers the opportunity cost of an individual to rise up, revolt or protest. And the second reason is that deprivation is increased by poor economic environment which fuels political crisis especially when the government is found incompetent. In addition, Blomberg and Hess (2002) [9] show empirically that low income growth may affect instability.

\section{3) Inflation}

A possible macroeconomic factor which influences the government to be stable or unstable is based on inflation rates in a country. Cukierman and Tabellini (1992) [10] in their study of inflation and political instability, find politically weak governments are highly likely to resort to seigniorage. However, Paldam (1987) [11] demonstrated that almost no regime in eight Latin America countries survived because of hyperinflation in the period of 1946-1983.

\section{4) Social Inequality}

According to Blanco and Grier (2009) [8], socio-demographic conditions (basically, ethnic fractionalization, economic discrimination of ethnic minorities and urban growth) have been shown as relevant determinants of political instability. However, it shows that more fractionalized countries are more prone to instability while urban growth has no significant effect on political instability (Annet 2000; Collier and Hoeffler 2004) [12] [13]. In addition, ethnic and linguistic fractionalization are the most widely applied measure, which exist in Madagascar where Malagasy ethnic is divided in two groups: "Merina" (in the capital city) and "Côtier" (in the coastal regions of Madagascar).

\subsection{Empirical Researches}

In this section, we will present previous literature made on relationship between political instability and economic growth which has been discussed by various researchers and is not new at all. The most prominent literatures are reviewed as follows: Political instability can affect economic growth in different number of channels. According to Aisen and Veiga (2013) [14], they find that total factor productivity is the main transmission channel through which political instability has a negative effect on growth. [2] Examine the links between political instability and economic growth, and they test the sample of 113 countries for the pe- 
riod of 1950-1982. During their study, they use simultaneous equations model and measure economic growth and political instability simultaneously by using Amemiya's Generalized Least Square technique (AGLS). They conclude that where there are high chances of government collapse, growth is considerably lower and vice-versa. Furthermore, the authors do not find any significant change of economic growth when authoritarian regimes are compared to democracies. The analysis of Alesina and Perotti (1996) [5] shows that there are two dimensions of political instability:

- Regime-related instability: Coups d'état, governmental crisis, purges, cabinet changes.

- Instability induced by civil-society: assassinations, general strikes, guerilla warfare, riots, revolutions, anti-governmental demonstrations.

[15] test the influence of political instability on economic growth for United Kingdom for the period of 1961-1997 by using time-series data. They use OLS regression technique and GARCH and GARCH-M models. Moreover, they construct the political instability index by employing principal component method. The researchers find that political instability and growth of UK GDP per capita are strongly negatively related to each other. [16] analyze the role of instabilities on Africa's low rates of growth during 1970 to 199, while they use cross-section statistical estimates to test a sample of African and non-African countries. And they also estimate impact of political instability on economic growth. The authors conclude that the political instability lowered the rate of GDP growth more through their effect on total factor productivity growth than by diminishing the rate of investment. [17] examines the interrelationships among democracy, political instability and economic growth. He uses the technique of three-stage least square on the cross country data of ninety-six countries for the time period of 1960-1980 by using simultaneous equation system. The estimation facts point out either there is constitutional government change or regime change, both have the significant reverse effects on growth. However, the growth is affecting regime change negatively and affecting positively the probability of the ruling party staying in power. [18] analyzes the inter-linkages between political crisis and economic growth. He uses the Cobb-Douglas production function and the data of different events of "coups d'état" of the Sub-Saharan African countries for the period of 1960-1986. In his conclusion, the author says that political crisis greatly hampers the economic growth in the Sub-Saharan African countries. So far, he adds that political crisis index is giving much more appropriate results than the coup variables separately. [19] study the connections between political instability and economic growth. They test a big sample of 39 Sub-Saharan African countries. The authors use simultaneous equations model and a dynamic panel estimation method for the estimation of time-series cross-national data for the period of 1975-88. In their conclusion, the negative relationship is identified between political instability and economic growth. [20] present rather amazing findings that political crisis hampers the economic growth significantly by con- 
centrating on a single country, Mexico, for the period of political instability 1910-1934 (this time period in Mexico was noticeable by revolutions, counter-revolutions, civil wars, military coups, and presidential assassinations). They exert that either there is political crisis or not, the government can flourish the economic performance just protecting the private property rights. That's opposing the general phenomena which political instability always worsens the economic performance. [21] observe the growth rates in 116 economies from 1965 to 1985 . The authors estimate five different variables impact on economic growth including political crisis. And they conclude that political crisis negatively affects economic growth. [22] look at the multiplicity of the relationship between economic growth and exports. The authors analyze the validity of their hypothesis based on the export-led growth by using 126 countries' annual data from 1965 to 1999. Bivariate, trivariate, and 5-variable models were the three types of co-integration procedures which they have been conducted. They have included the variable of real import growth as one of the explanatory variables which is different from the previous literature. The researchers stated that they did not find any short-run causal effect in the bivariate and five variable causality tests in Malaysia.

\section{Research Methodology}

\subsection{Data Collection}

This paper used mainly secondary data which were sourced from National Institute of Statistics of Madagascar (INSTAT) [23], International Monetary Fund (IMF), World Bank (2011) [24] and Central Bank of Madagascar [25]. Data from the above sourced were cross-checked and matched to ensure uniformity. In addition, the export values and quantities were investigated using the import data for the USA and EU in the Global trade Atlas, which are respectively from US International Trade Commission data and EUROSTAT.

\subsection{Estimation Method and Model}

As we try to identify the impacts of political instability on vanilla exports, we require information from abroad to distinguish the effects of political instability from financial crisis. To estimate the impacts of political instability on vanilla exports, the international trade data allow us to isolate those impacts from various factors to Madagascar and other vanilla exporting countries by using the different-in-different (DID) technique. To avoid extraordinary fluctuation in export, we selected the exporting countries that take share in USA and EU markets with more than $0.1 \%$. Our methodology requests the assumption that domestic political instability systematically and differently affected vanilla exports from Madagascar compared with other countries. The suspension of AGOA due to the political instability is the most likely factor to cause differential changes in exports between Madagascar and other countries. So our analysis is restricted to the period before 2009 or vanilla export to the EU market. Access to the EU 
market applied to least developed countries (LDC) changed in 2011 with the relaxing of the rule of origin from double to single transformation, which is equivalent to the one applied to Madagascar. While it affects performance of Madagascar's exporters to the EU market, it does not affect our analysis until 2010. As we know that some Madagascar companies export Vanilla to USA and other markets. Our fundamental assumption is that the suspension of AGOA systematically and differently affects changes of vanilla exports to the USA market compared with those to the EU market. We apply the difference-in-differencesin-differences (DIDID) method in order to avoid the possible bias. This method takes the difference in changes of vanilla export volume in the USA market as well as in the EU market resulting from Madagascar and the same difference from other exporting countries. We consider only two periods 2009 and 2010, and two countries for simplicity, it is expressed as follows:

$$
\begin{aligned}
D I D I D= & {\left[\left(\ln V_{2010}^{\mathrm{MD}, \mathrm{USA}}-\ln V_{2009}^{\mathrm{MD}, \mathrm{USA}}\right)-\left(\ln V_{2010}^{\mathrm{MD}, \mathrm{EU}}-\ln V_{2009}^{\mathrm{MD}, \mathrm{EU}}\right)\right] } \\
& -\left[\left(\ln V_{2010}^{\text {Other,USA }}-\ln V_{2009}^{\text {Other,USA }}\right)-\left(\ln V_{2010}^{\text {Other,EU }}-\ln V_{2009}^{\text {Other,EU }}\right)\right]
\end{aligned}
$$

where:

$\ln V_{2010}^{\mathrm{MD}, \mathrm{USA}}=$ the $\log$ of the value of Vanilla imports from Madagascar to the USA in 2010;

$\ln V_{2010}^{\text {Other,USA }}=$ the $\log$ of the value of Vanilla imports from another country to the USA in 2010;

$\ln V_{2010}^{\mathrm{MD}, \mathrm{EU}}=$ the $\log$ of the value of Vanilla imports from Madagascar to the European Union in 2010 and;

$\ln V_{2010}^{\text {Other,EU }}=$ the $\log$ of the value of Vanilla imports from another country to the European Union in 2010.

This operation allows for changes in demand in markets irrelevant to suspension of AGOA to be excluded from our estimation. For factory-level changes, DIDID cannot be applied and its estimation, based on DID, is susceptible to possible violation of the assumption mentioned earlier. Complete differences in characteristics between control and treatment groups, namely exporters to the USA and those to other markets are controlled.

Following are the hypotheses of this study:

$\mathrm{H}_{1}$ : Political instability affects negatively Madagascar vanilla exports to USA and EU markets in 2009.

$\mathrm{H}_{2}$ : Suspension of AGOA deteriorates Madagascar vanilla export to USA.

\section{Research Findings and Interpretation}

The main objective of the current study is to test the hypothesis that the political instability affects negatively Madagascar vanilla exports to USA and EU markets. The vanilla exports from Madagascar to the USA and EU markets decreased $4.9 \%$ in 2008 , and this reduction reached significantly $18.0 \%$ in 2009 and $38.5 \%$ in 2010 [23]. The reduction was much greater for vanilla exports to the USA, with a $74.0 \%$ reduction following to the suspension of AGOA in 2010 due to the 
political crisis in Madagascar. In contrast, the vanilla exports to the EU markets noticed a significant growth of $28.0 \%$ in 2011 . We use the world export trend as a control in order to separate the impact of the political crisis from overall changes in vanilla exports. The estimation model is shown as follows:

$$
\ln V_{v, x, m, t}=\alpha_{0+} \alpha_{1} \text { Crisis }_{x, t}+\beta \text { year }_{t}+{\text { Vanilla } * \text { Country } * \text { Market }_{v, x, m}} .
$$

where:

$\ln V=$ represents the $\log$ of the value of Vanilla imports in the USA or EU markets at the six-digit different quality of vanilla in the Harmonized System (HS);

Crisis $=$ a dummy variable and takes one for imports from Madagascar after 2009;

Year = a dummy for a set of years;

Vanilla ${ }^{*}$ country ${ }^{*}$ market $=$ represents the fixed effect, and $v, x, m$, and $t$ indicate respectively a product at the six-digit level, country, market, and time ${ }^{1}$.

The DID estimate is $\alpha_{1}$, and a triple interaction term is incorporated to control the possible impact of AGOA suspension. We also estimated the above model using import value only in the EU market, dropping the triple interaction term. We include the observations with zero import value to estimate the extensive and intensive margins. But, we also need to insert 1 (dollar) for these observations in order to get the logarithm. Tobit model with Random Effect (RE) is applied in addition to OLS with Fixed Effect (FE) to seeing the sensitivity of including these censored observations [26]. And the following Table 1 reports the results of these estimations:

In Table 1, Columns 1 and 2 show the effects of the political crisis on vanilla exports to USA and EU markets in 2009, which are negative and significant only in the Tobit model. Columns 3 and 4 summarize the estimated effects in the EU vanilla market in 2009 and 2010 which are negative and significant. For those with statistical significance, estimated impact ranges from $31.1 \%$ to $45.3 \%$ with larger effect in Tobit model as expected. Point estimates are larger in the models covering only the EU vanilla market. Therefore, when we estimated separately the USA and EU vanilla market, we observed no significant difference impacts on their markets in 2009, rather, it is due to the larger estimated impact in 2010.

To analyze the measurement of the impact of AGOA suspension, DIDID using imports in the USA and EU vanilla markets from six low-income countries is applied in the following form:

$$
\begin{aligned}
\ln V_{v, x, m, t}= & \beta_{0}+\beta_{1}\left(U S A_{m} \times M G_{x}\right)+\beta_{2}\left(U S A_{m} \times y_{r} 2010_{t}\right)+\beta_{3}\left(M D_{x} \times y_{r} 2010_{t}\right) \\
& + \text { year }_{t}+\text { Vanilla } * \text { Country } * \text { Market }_{v, x, m}
\end{aligned}
$$

where:

$U S A=$ a market dummy (equal to 1 if observations represent import values in the $U S A$ );

${ }^{1}$ Compared with the standard DID model, we added year dummies and applied the vanilla-country-market fixed effect rather than the product fixed effect and market and country dummies to allow for flexibility in the base level. 
Table 1. Impact of Political crisis ${ }^{\mathrm{a}}$.

\begin{tabular}{|c|c|c|c|c|}
\hline & \multicolumn{2}{|c|}{ USA and EU market (2007-2009) } & \multicolumn{2}{|c|}{ EU market (2007-2010) } \\
\hline & $\begin{array}{c}\text { OLS FE } \\
1\end{array}$ & $\begin{array}{c}\text { Tobit RE } \\
2\end{array}$ & $\begin{array}{c}\text { OLS FE } \\
3\end{array}$ & $\begin{array}{c}\text { Tobit RE } \\
4\end{array}$ \\
\hline $\mathrm{MD}^{*}$ post 2009 & $\begin{array}{l}-0.1381 \\
(0.1871)\end{array}$ & $\begin{array}{c}-0.4632^{* *} \\
(0.2352)\end{array}$ & $\begin{array}{l}-0.3730^{*} \\
(0.2191)\end{array}$ & $\begin{array}{c}-0.6451^{* *} \\
(0.2910)\end{array}$ \\
\hline yr2007 & $\begin{array}{l}-0.1062^{\star *} \\
(0.0541)\end{array}$ & $\begin{array}{c}-0.1321^{* *} \\
(0.0662)\end{array}$ & $\begin{array}{c}-0.1563^{* *} \\
(0.0691)\end{array}$ & $\begin{array}{c}-0.1880^{* *} \\
(0.0830)\end{array}$ \\
\hline yr2009 & $\begin{array}{l}-0.0121 \\
(0.0562)\end{array}$ & $\begin{array}{c}0.0243 \\
(0.0641)\end{array}$ & $\begin{array}{c}0.1424 \\
(0.0623)\end{array}$ & $\begin{array}{c}0.1910^{* * *} \\
(0.0701)\end{array}$ \\
\hline yr2010 & & & $\begin{array}{c}0.2761^{* * *} \\
(0.0701)\end{array}$ & $\begin{array}{c}0.3490^{* * *} \\
(0.0820)\end{array}$ \\
\hline _cons & $\begin{array}{c}-3.6381^{* * *} \\
(0.0310)\end{array}$ & $\begin{array}{c}-4.4112^{\star * *} \\
(0.1621)\end{array}$ & $\begin{array}{c}-3.2873^{\star * *} \\
(0.0432)\end{array}$ & $\begin{array}{c}-3.8340^{* * *} \\
(0.1821)\end{array}$ \\
\hline $\begin{array}{c}\text { Fixed/Random } \\
\text { effect }\end{array}$ & $\begin{array}{l}\text { vanilla*country } \\
{ }^{*} \text { market }\end{array}$ & $\begin{array}{c}\text { vanilla* country } \\
{ }^{*} \text { market }\end{array}$ & vanilla ${ }^{*}$ country & $\begin{array}{c}\text { vanilla }{ }^{*} \text { country } \\
{ }^{*} \text { market }\end{array}$ \\
\hline $\begin{array}{l}\text { Marginal effect of } \\
\text { political crisis }\end{array}$ & $-12.90 \%$ & $-33.82 \%$ & $-31.11 \%$ & $-45.33 \%$ \\
\hline $\mathrm{R} 2$ & 0.0009 & & 0.0090 & \\
\hline Log likelihood & & -20164.571 & & -13215.270 \\
\hline $\mathrm{N}$ & 8283 & 8283 & 5732 & 5732 \\
\hline
\end{tabular}

Source: Author's Estimation. ${ }^{a}$ Remark: Numbers in parentheses represent clustered standard errors for OLS and bootstrap standard errors for the Tobit model. The marginal effect of political crisis is obtained by [Exp (coef.) - 1 $]^{\star} 100$, where the coefficient of Tobit models is transformed to indicate marginal effect on observed (censored) dependent variable meanwhile ${ }^{*}{ }^{* *}$, and ${ }^{* *}$ indicate respectively $\mathrm{p}<0.1,0.05$, and 0.01 .

$\mathrm{y}_{\mathrm{r}} 2010=$ a dummy for year 2010 when AGOA is suspended and;

$M D=$ represents a dummy for a country from which a product is exported (it is 1 if an observation represents vanilla exports from Madagascar and 0 if it represents vanilla exports from the other countries) and the triple DID estimate is $\beta_{1}$.

Table 2 shows the results of AGOA suspension (column 1 and 2) which its effect is shown in the coefficients on the triple interaction term (USA $\left.{ }^{*} \mathrm{MD}^{\star} \mathrm{y}_{\mathrm{r}} 2010\right)$. The coefficients are negative and very large in both models. The DIDID estimate by OLS with fixed effects assumes that the suspension of AGOA decreased the value of vanilla imports by $63.6 \%$ on an average at the six-digit product level. Besides, a reduction of $78.1 \%$ is shown by the Tobit estimate. Hence, we can see here that the suspension of the duty-free access has made larger impact than the political turmoil itself. Note that the DIDID results indicate that if impact is estimated by DID of USA vanilla import from Madagascar and EU vanilla import, estimate entails downward bias. The DID estimation does not isolate common changes of import in the vanilla market from changes specific to import from Madagascar. The former changes are negative and significant as indicated by the coefficient of USA ${ }^{\star} \mathrm{y}_{\mathrm{r}} 2010$ in the DIDID model. Consequently, DID estimate of effect of AGOA suspension will be smaller 
Table 2. Impact of AGOA suspension ${ }^{\mathrm{a}}$.

\begin{tabular}{|c|c|c|c|c|}
\hline & \multicolumn{2}{|c|}{ DIDID } & \multicolumn{2}{|c|}{ DID } \\
\hline & OLS FE (2) & Tobit RE (1) & OLS FE (4) & Tobit RE (3) \\
\hline $\mathrm{USA}^{*} \mathrm{MD}^{*} \mathrm{y}_{\mathrm{r}} 2010$ & $\begin{array}{l}-1.0121^{* * *} \\
(0.3670)\end{array}$ & $\begin{array}{c}-1.7730^{* * *} \\
(0.5462)\end{array}$ & & \\
\hline $\mathrm{USA}^{*} \mathrm{y}_{\mathrm{r}} 2010$ & $\begin{array}{c}-0.2492^{* * *} \\
(0.0951)\end{array}$ & $\begin{array}{c}-0.3351^{\star *} \\
(0.1122)\end{array}$ & $\begin{array}{c}-1.2610^{* * *} \\
(0.3551)\end{array}$ & $\begin{array}{c}-2.5213^{\star *} \\
(0.6021)\end{array}$ \\
\hline $\mathrm{y}_{\mathrm{r}} 2007$ & $\begin{array}{l}-0.1061 \\
(0.0542)\end{array}$ & $\begin{array}{c}-0.1332^{\star *} \\
(0.0641)\end{array}$ & $\begin{array}{l}-0.1453 \\
(0.2023)\end{array}$ & $\begin{array}{l}-0.2430 \\
(0.3331)\end{array}$ \\
\hline $\mathrm{y}_{\mathrm{r}} 2009$ & $\begin{array}{l}-0.0321 \\
(0.0552)\end{array}$ & $\begin{array}{l}-0.0401 \\
(0.0641)\end{array}$ & $\begin{array}{l}-0.1690 \\
(0.1981)\end{array}$ & $\begin{array}{l}-0.3112 \\
(0.3150)\end{array}$ \\
\hline $\mathrm{y}_{\mathrm{r}} 2010$ & $\begin{array}{l}0.2470^{* * *} \\
(0.0632)\end{array}$ & $\begin{array}{c}0.3322^{* * *} \\
(0.0702)\end{array}$ & $\begin{array}{l}-0.1401 \\
(0.2770)\end{array}$ & $\begin{array}{l}-0.0800 \\
(0.4152)\end{array}$ \\
\hline $\mathrm{MD}^{\star} \mathrm{y}_{\mathrm{r}} 2010$ & $\begin{array}{l}-0.3281 \\
(0.2452)\end{array}$ & $\begin{array}{c}-0.5310 \\
(0.331)\end{array}$ & & \\
\hline _cons & $\begin{array}{c}-3.6381^{* * *} \\
(0.0350)\end{array}$ & $\begin{array}{c}-4.4230^{\star * *} \\
(0.1461)\end{array}$ & $\begin{array}{l}-6.5521^{\star * *} \\
(0.1272)\end{array}$ & $\begin{array}{l}-8.5070^{* * *} \\
(0.5311)\end{array}$ \\
\hline Fixed/Random effect & $\begin{array}{c}\text { vanilla }{ }^{*} \text { country } \\
{ }^{*} \text { market }\end{array}$ & $\begin{array}{c}\text { vanilla*country } \\
{ }^{*} \text { market }\end{array}$ & vanilla* country & vanilla $^{*}$ country \\
\hline $\begin{array}{l}\text { Marginal effect of } \\
\text { AGOA suspension }\end{array}$ & $-63.60 \%$ & $-78.12 \%$ & $-71.70 \%$ & $-81.6 \%$ \\
\hline $\mathrm{R}^{2}$ & 0.0009 & & 0.0210 & \\
\hline Log likelihood & & -25997.480 & & -3592.81 \\
\hline $\mathrm{N}$ & 11044 & 11044 & 1592 & 1592 \\
\hline
\end{tabular}

Source: Author's Estimation. ${ }^{\mathrm{a} R e m a r k}$ : Numbers in parentheses represent clustered standard errors for OLS and bootstrap standard errors for the Tobit model. The marginal effect of political crisis is obtained by [Exp (coef.) -1$]^{*} 100$, where the coefficient of Tobit models is transformed to indicate marginal effect on observed (censored) dependent variable meanwhile ${ }^{\star},{ }^{* *}$, and ${ }^{\star * *}$ indicate respectively $\mathrm{p}<0.1,0.05$, and 0.01 .

than estimate by DIDID, and thus, adverse impact will be overestimated. Finally, we run DID model and found that estimated effect is larger by $4.5 \%$ to $12.7 \%$ than those in the DIDID model (column 3 and 4).

\section{Conclusions and Policies Recommendations}

Although, the vanilla production displayed robust growth in 2003, overcoming the market liberalization in 1990, this sector experienced a critical effect after the domestic political instability in 2009. Our analysis indicates that the political instability has negatively affected the vanilla exports (reduction of Vanilla exports by $31 \%$ to $45 \%$ ). And it is more drastic when the main importers (USA) of Madagascar vanilla have suspended the duty-free access (the AGOA) to the USA vanilla market due to the government instability or political crisis. Furthermore, the estimated results show that suspension of AGOA caused exports to the USA vanilla market to fall by $64 \%$ to $78 \%$ which reveals that political instability reduces significantly economic growth.

In terms of vanilla production, Madagascar has never been able to industrial- 
ize this sector even though we have been trading with USA and EU for several decades. At the absence of the processing industry of its products, therefore, the researcher recommends for stronger policies and regulations in efforts from the competent authority to revive the vanilla sector in order to boost the vanilla exportation not only to USA and EU but also worldwide. Furthermore, the Malagasy government needs to intervene and have bilateral talks with other countries in efforts to lure overseas investors who can input technological and innovation aspects in vanilla production by setting up the factory of transformation of vanilla in Madagascar.

\section{References}

[1] ANDREAS Claude (2006) Pour une meilleure compétitivité de la vanille de Madagascar (2ème) Atelier National Vanille, Antananarivo.

https://www.doc-developpement-durable.org/file/Culture-vanille/Vanille060928_0. pdf

[2] Alesina, A., Ozler, S., Roubini, N. and Swagel, P. (1996) Political Instability and Economic Growth. Journal of Economic Growth, 1, 189-211. https://doi.org/10.1007/BF00138862

[3] Lipset, S.M. (1960) Political Man: The Social Bases of Politics. Library of Congress, United States of America, 83-90.

[4] Miljkovic, D. and Rimal, A. (2008) The Impact of Socio-Economic Factors on Political Instability: A Cross-Country Analysis. Journal of Socio-Economic, 37, 2454-2463. https://doi.org/10.1016/j.socec.2008.04.007

[5] Alesina, A. and Perotti, R. (1996) Income Distribution, Political Instability, and Investment. European Economic Review, 40, 1203-1228.

https://doi.org/10.1016/0014-2921(95)00030-5

[6] Roberto, P. (1996) Growth, Income Distribution, and Democracy: What the Data Say. Journal of Economic Growth, 1, 149-187. https://doi.org/10.1007/BF00138861

[7] Edward, N.M. (1985) Income Inequality, Regime Repressiveness, and Political Violence. American Sociological Review, 50, 47-61.

http://www.jstor.org/stable/2095339 https://doi.org/10.2307/2095339

[8] Blanco, L. and Grier, R. (2009) Long Live Democracy: The Determinants of Political Instability in Latin America. Journal of Developmental Studies, 45, 76-95. https://doi.org/10.1080/00220380802264788

[9] Blomberg, S.B. and Hess, G.D. (2002) The Temporal Links between Conflict and Economic Activity. Journal of Conflict Resolution, 46, 74-90. https://doi.org/10.1177/0022002702046001005

[10] Cukierman, A., Edwards, S. and Tabellini, G. (1992) Seigniorage and Political Instability. American Economic Review, 82, 537-555.

[11] Paldam, M. (1987) Inflation and Political Instability in Eight Latin American Countries 1946-83. Public Choice, 52, 143-168. https://doi.org/10.1007/BF00123874

[12] Annett, A. (2000) Social Fractionalization, Political Instability, and the Size of Government. IMF Working Paper 82. International Monetary Fund, Washington DC. https://www.imf.org/external/pubs/ft/wp/2000/wp0082.pdf

[13] Collier, P. and Hoeffler, A. (2004) Greed and Grievance in Civil War. Oxford Economic Papers, 56, 563-595. https://doi.org/10.1093/oep/gpf064 
[14] Aisen, A. and Veiga, F.J. (2013) How Does Political Instability Affect Economic Growth? European Journal of Political Economy, 29, 151-167. https://doi.org/10.1016/j.ejpoleco.2012.11.001

[15] Asteriou, D. and Simon, P. (2001) Political Instability and Economic Growth: UK Time Series Evidence. Scottish Journal of Political Economy, 48, 383-399. https://doi.org/10.1111/1467-9485.00205

[16] Guillaumont, P., Jeanneney, S.G. and Brun, J.F. (1999) How Instability Lowers African Growth. Journal of African Economies, 8, 87-107. https://doi.org/10.1093/jae/8.1.87

[17] Feng, Y. (1997) Democracy, Political Stability and Economic Growth. British Journal of Political Science, 27, 391-418. https://doi.org/10.1017/S0007123497000197

[18] Fosu, A.K. (2001) Political Instability and Economic Growth in Developing Economies: Some Specification Empirics. Economic Letters, 70, 289-294. https://doi.org/10.1016/S0165-1765(00)00357-8

[19] Gyimah-Brempong, K. and Traynor, T.L. (1999) Political Instability, Investment and Economic Growth in Sub-Saharan Africa. Journal of African Economies, 8, 52-86. https://doi.org/10.1093/jae/8.1.52

[20] Haber, S., Maurer, N. and Razo, A. (2003) The Politics of Property Rights: Political Instability, Credible Commitments, and Economic Growth in Mexico, 1876-1929. Cambridge University Press, Cambridge. https://doi.org/10.1017/CBO9780511615610

[21] Barro, R.J. and Lee, J. (1994) Sources of Economic Growth. Carnegie-Rochester Conference Series on Public Policy, 40, 1-46. https://doi.org/10.1016/0167-2231(94)90002-7

[22] Riezman, R.G., Whiteman, C.H. and Summers, P.M. (1996) The Engine of Growth or Its Handmaiden? Long-Run Economic Growth. Studies in Empirical Economics. Physica-Verlag HD, Heidelberg, 77-110. https://doi.org/10.1007/BF01205495

[23] National Institute of Statistics of Madagascar (2011). http://www.instat.mg/

[24] World Bank (2011) World Development Indicators. http://data.worldbank.org/data-catalog/world-development-indicators

[25] Central Bank of Madagascar (2010). http://www.banque-centrale.mg/

[26] Wooldridge, J.M. (2009) Introductory Econometrics: A Modern Approach. 4th Edition, South-Western College Publishing, Cengage Learning, Boston, 22-68. 